RESEARCH PAPER

\title{
Tobacco use in India: prevalence and predictors of smoking and chewing in a national cross sectional household survey
}

\author{
M Rani, S Bonu, P Jha, S N Nguyen, L Jamjoum
}

Tobacco Control 2003;12:e4 (http://www.tobaccocontrol.com/cgi/content/full/12/4/e4)

\begin{abstract}
Objective: To estimate the prevalence and the socioeconomic and demographic correlates of tobacco consumption in India.

Design: Cross sectional, nationally representative population based household survey.

Subjects: 315598 individuals 15 years or older from 91196 households were sampled in National Family Health Survey-2 (1998-99). Data on tobacco consumption were elicited from household informants.

Measures and methods: Prevalence of current smoking and current chewing of tobacco were used as outcome measures. Simple and two way cross tabulations and multivariate logistic regression analysis were the main analytical methods.

Results: Thirty per cent of the population 15 years or older $-47 \%$ men and $14 \%$ of women-either smoked or chewed tobacco, which translates to almost 195 million people-154 million men and 41 million women in India. However, the prevalence may be underestimated by almost $11 \%$ and $1.5 \%$ for chewing tobacco among men and women, respectively, and by $5 \%$ and $0.5 \%$ for smoking among men and women, respectively, because of use of household informants. Tobacco consumption was significantly higher in poor, less educated, scheduled castes and scheduled tribe populations. The prevalence of tobacco consumption increased up to the age of 50 years and then levelled or declined. The prevalence of smoking and chewing also varied widely between different states and had a strong association with individual's sociocultural characteristics.

Conclusion: The findings of the study highlight that an agenda to improve health outcomes among the poor in India must include effective interventions to control tobacco use. Failure to do so would most likely result in doubling the burden of diseases - both communicable and non-communicable-among India's teeming poor. There is a need for periodical surveys using more consistent definitions of tobacco use and eliciting information on different types of tobacco consumed. The study also suggests a need to adjust the prevalence estimates based on household informants
\end{abstract}

Correspondence to: Manju Rani; Indian Administrative Services, N30, Bajaj Nagar Jaipur, India 302015

mrani@jhsph.edu

Received 22 April 2003 Accepted

10 September 2003

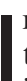
n India, tobacco consumption is responsible for half of all the cancers in men and a quarter of all cancers in women, in addition to being a risk factor for cardiovascular diseases and chronic obstructive pulmonary diseases. ${ }^{2}{ }^{3}$ India also has one of the highest rates of oral cancer in the world, partly attributed to high prevalence of tobacco chewing. ${ }^{4-7}$ Forms of tobacco chewing include pan (piper betel leaf filled with sliced areca nut, lime, catechu, and other spices chewed with or without tobacco), pan-masala or gutkha (a chewable tobacco containing areca nut), and mishri (a powdered tobacco rubbed on the gums as toothpaste).

The World Health Organization predicts that tobacco deaths in India may exceed 1.5 million annually by $2020{ }^{8}$ However, considerable research is required to comprehend the actual trends. Nationally representative and reliable prevalence data on tobacco consumption are scarce. Similarly, the sociodemographic predictors of tobacco smoking and chewing are poorly understood. The existing studies on prevalence of tobacco use are based on non-representative sample surveys or have been conducted in localised-mostly urban-geographical areas as reviewed in table 1. ${ }^{1-14}$ WHO estimated a prevalence of tobacco consumption of all forms at $65 \%$ and $33 \%$, respectively, among men and women, based on small scale studies conducted in the past (table 1).

The 52nd of National Sample Survey (52nd NSS) conducted by the National Sample Survey Organization in 1995-96 was the first nationally representative household survey to collect data on tobacco consumption for population 10 years and older using surrogate household informants.
Two questions were asked to elicit data on tobacco consumption: "whether the household member regularly consumes 'biri/cigar/cigarette/hukka'?" and "whether the household member regularly consumes 'tobacco'?". The second question was very ambiguous and did not explicitly ask about "chewing" tobacco. Though the prevalence estimates from the survey were not published, the authors calculated a prevalence rate of tobacco consumption of any form of tobacco consumption at $51.3 \%$ for men and $10.3 \%$ for women 15 years and older (table 1), which was lower than that estimated by WHO and other small studies based on special population groups in small geographical areas. The review of the prevalence studies in table 1 also points to the dearth of representative prevalence estimates in India.

This study uses data from National Family Health Survey (NFHS-2) to provide nationally representative estimates of prevalence, and socioeconomic and demographic correlates of current tobacco consumption-both smoking and chewingamong individuals 15 years and older in India. The findings of the study will help in designing tobacco control strategies

Abbreviations: DALYS, disability adjusted life years; NFHS-2, National Family Health Survey; NSS, National Sample Survey, OBCs, other backward castes; PSU, primary sampling unit; SCs, scheduled castes; STs, scheduled tribes; VIF, variance inflation factor; WHO, World Health Organization 
Table 1 Review of literature on prevalence of tobacco consumption in India

\begin{tabular}{|c|c|c|c|c|c|}
\hline Reference & Study population & Sample size & Year & $\begin{array}{l}\text { Prevalence of tobacco } \\
\text { consumption (indicators } \\
\text { presented in the published study) }\end{array}$ & $\begin{array}{l}\text { Comparative estimates for the } \\
\text { same comparable sub-sample } \\
\text { of population from the current } \\
\text { study based on authors' calculations }\end{array}$ \\
\hline \multicolumn{6}{|l|}{ National level studies } \\
\hline $\begin{array}{l}\text { National } \\
\text { Sample Survey } \\
\text { Organization } \\
\text { (1998) and } \\
\text { author's } \\
\text { calculations }\end{array}$ & $\begin{array}{l}\text { 52nd round; nationally } \\
\text { representative survey of all } \\
\text { the states and union territories. } \\
\text { The data were elicited using } \\
\text { household informants }\end{array}$ & $\begin{array}{l}396546 \\
\text { individuals } 15 \\
\text { years and } \\
\text { above }\end{array}$ & $1995-96$ & $\begin{array}{l}51.3 \% \text { men and } 10.3 \% \text { women } \\
\text { consumed some form of tobacco; } \\
19.2 \% \text { current smokers ( } 35.3 \% \\
\text { men and } 2.6 \% \text { women), } 16.4 \% \\
\text { ( } 24 \% \text { men and } 8.6 \% \text { women) } \\
\text { chew tobacco }\end{array}$ & $\begin{array}{l}47 \% \text { of men and } 14 \% \text { of women } \\
\text { consumed some form of tobacco; } \\
16.2 \% \text { current smokers ( } 29.4 \% \\
\text { men and } 2.3 \% \text { women) and } 20.5 \% \\
\text { chew tobacco ( } 28.3 \% \text { men and } \\
18 \% \text { women) }\end{array}$ \\
\hline $\begin{array}{l}\text { WHO } \\
(1997)^{1}\end{array}$ & $\begin{array}{l}\text { Sample size or } \\
\text { methodology not known }\end{array}$ & $\begin{array}{l}15 \text { years and } \\
\text { above }\end{array}$ & 1997 & $\begin{array}{l}65 \% \text { of all men and } 33 \% \text { of all } \\
\text { women consumed some form of } \\
\text { tobacco; smoking } 35 \% \text { of all men } \\
\text { and } 3 \% \text { of female }\end{array}$ & $\begin{array}{l}47 \% \text { of men and } 14 \% \text { of women } \\
\text { consumed some form of tobacco; } \\
29.4 \% \text { of men and } 2.3 \% \text { of } \\
\text { women smoked }\end{array}$ \\
\hline \multicolumn{6}{|c|}{ 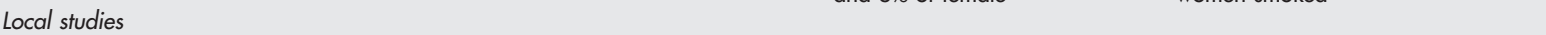 } \\
\hline Kutty et al $(1990)^{9}$ & $\begin{array}{l}\text { Rural population of } \\
\text { Thiruvananthapuram } \\
\text { district, Kerala }\end{array}$ & $\begin{array}{l}1130 \\
\text { respondents } \\
\text { aged 25-64 } \\
\text { years }\end{array}$ & 1990 & $\begin{array}{l}\text { Overall smoking prevalence } \\
21.9 \%(15.1-28.7 \%)\end{array}$ & $18.5 \%(17.1-20 \%)$ in rural Kerala \\
\hline $\begin{array}{l}\text { Venkat Narayan } \\
\text { et al }(1996)^{10}\end{array}$ & $\begin{array}{l}\text { Population based } \\
\text { representative study } \\
\text { in Delhi urban sample } \\
\text { based on sampling frame } \\
\text { of } 1981 \text { census population }\end{array}$ & $\begin{array}{l}13558 \\
\text { individuals } \\
25-64 \text { years }\end{array}$ & $1985-86$ & $\begin{array}{l}45 \%(43.8-46.2 \%) \text { of men } \\
\text { and } 7 \%(6.4-7.6 \%) \text { of women } \\
\text { were smokers }\end{array}$ & $\begin{array}{l}32.7 \%(30 \%-35.5 \%) \text { men and } 2.3 \% \\
\text { women } \\
(1.8 \% \text { to } 2.9 \%) \text { in Delhi }\end{array}$ \\
\hline Gupta (1996) ${ }^{11}$ & $\begin{array}{l}\text { Bombay urban sample; } \\
\text { cross sectional individual } \\
\text { self reports, population } \\
\text { based with under-sampling } \\
\text { of upper middle and higher } \\
\text { economic classes }\end{array}$ & $\begin{array}{l}99598 \\
\text { individuals } \\
\text { (60\% women, } \\
40 \% \text { men) } 35 \\
\text { years and older }\end{array}$ & 1992-94 & $\begin{array}{l}57.5 \% \text { prevalence of tobacco } \\
\text { use in women, } 69.3 \% \text { current } \\
\text { tobacco use in men. } 23.6 \% \text { of } \\
\text { men were smokers }\end{array}$ & $\begin{array}{l}18.3 \%(15.0-22.0 \%) \text { women and } \\
43.7 \%(39.5-48.1 \%) \text { men use } \\
\text { tobacco; } 21 \%(18.1-24.1 \%) \text { men } \\
\text { smoked tobacco }\end{array}$ \\
\hline Gupta et al (1997) ${ }^{12}$ & $\begin{array}{l}\text { Census sampling in three } \\
\text { villages in Naguar district } \\
\text { in Rajasthan }\end{array}$ & $\begin{array}{l}1982 \text { men and } \\
1060 \text { women } \\
20 \text { years or } \\
\text { older }\end{array}$ & NA & $\begin{array}{l}51 \% \text { of men and } 5 \% \text { of women } \\
\text { smoked tobacco }\end{array}$ & $\begin{array}{l}50.5 \%(48.1-53.0 \%) \text { men and } 6.0 \% \\
(4.6-7.9 \%) \text { women }\end{array}$ \\
\hline $\begin{array}{l}\text { Shah and Vaite } \\
(2002)^{13}\end{array}$ & $\begin{array}{l}\text { Pavement dwellers in } \\
\text { Mumbai, India; accidental } \\
\text { sampling }\end{array}$ & $\begin{array}{l}400 \text { pavement } \\
\text { dwellers ( } 83 \% \\
\text { male of average } \\
\text { age } 33 \text { years) }\end{array}$ & 2002 & $\begin{array}{l}86 \% \text { reported using tobacco. } \\
\text { Raw tobacco used by more than } \\
\text { half, 30\% smoked bidis, } 24 \% \\
\text { used pan, } 20 \% \text { used gutkha, and } \\
8 \% \text { smoked cigarettes. }\end{array}$ & $\begin{array}{l}\text { No comparable sample can be } \\
\text { defined }\end{array}$ \\
\hline $\begin{array}{l}\text { Shah S and Vaite } S \\
(2002)^{14}\end{array}$ & $\begin{array}{l}\text { Street children in Mumbai, } \\
\text { India; accidental sampling }\end{array}$ & $\begin{array}{l}400 \text { street } \\
\text { children, } 6-19 \\
\text { years old (mean } \\
\text { age was } 15 \\
\text { years, } 98 \% \\
\text { were male) }\end{array}$ & 2002 & $\begin{array}{l}46.8 \% \text { used gutkha, } 39.5 \% \\
\text { smoked bidis, } 28 \% \text { smoked } \\
\text { cigarettes }\end{array}$ & $\begin{array}{l}\text { No comparable sample can be } \\
\text { defined }\end{array}$ \\
\hline
\end{tabular}

and understanding epidemiology of tobacco related health burden in India.

\section{DATA AND METHODS}

The data for the study came from the household questionnaire fielded under NFHS-2 - a nationally representative, cross sectional, household sample survey conducted in 199899 covering $99 \%$ of India's population living in 26 states (the administrative divisions in India). The survey did not cover $1 \%$ of the population living in union territories (the administrative divisions directly under the control of central government) of India. A uniform sample design was adopted in all the states, which is described elsewhere in detail. ${ }^{15}$ Briefly, in each state the sample was selected in two stages: the selection of villages and urban blocks (primary sampling units) with probability proportional to size in the first stage, followed by random selection of households within each primary sampling unit in the second stage. The sample was stratified according to a number of variables in each state. These included regions, sub-regions, village size, percentage of males in the non-agricultural sector, percentage of scheduled castes and scheduled tribes, and female literacy. ${ }^{15}$

The sample size was large enough to provide reliable estimates of prevalence of tobacco consumption by sex and for different socioeconomic population groups for each of the 26 states. A sample of 91196 households yielded 334553 individuals_-160 871 men and 154726 women-15 years and older, which constituted the study population for estimating the prevalence of tobacco consumption.

The questionnaire was administered face-to-face to the head of the household or to any other competent adult member of the household. Fifty nine per cent of the household respondents were female. Majority of the respondents were in age groups 25-39 (42.6\%) and 40-59 years $(30.9 \%) ; 14.5 \%$ of the respondents were $15-24$ years old while the rest $(12.0 \%)$ of respondents were 60 years and older. Only $27.8 \%$ of the respondents reported themselves to be the head of household. The respondent to the household questionnaire was first asked to list all the usual residents and visitors who stayed in the household the night before the interview. Data for tobacco consumption for each household member 15 years and older including the household respondent were elicited with the help of two questions: does "he or she chews pan masala or tobacco?" or "smokes tobacco?". The individuals were classified as "chewing tobacco" if the household respondent answered "yes" to the question on chewing tobacco. Similarly, individuals were categorised as "smokers" if household respondent answered "yes" to the question on "smoking tobacco". No questions were asked on the amount or frequency of tobacco consumption and on the type of tobacco smoked-biris or cigarettes or other forms of smoking prevalent in India 
(chutta, hukka, etc), which is an important data limitation of the study.

Socioeconomic and demographic information were sought from the household informant at both household level (ownership of different assets, caste, religion) and at individual level (for example, age, sex, education, marital status) for all the household members. Socioeconomic differentials of tobacco prevalence were assessed with respect to three measures of socioeconomic status-caste, education, and household wealth. The caste is the basis of social hierarchical organisation of the Hindu religion-the predominant religion followed in India. The government of India has identified, in a schedule of the Constitution of India, the castes occupying the lowest rung of social hierarchy as the most socially disadvantaged, and classified them as scheduled castes (SCs) and the scheduled tribes (STs). In addition, the government has identified some occupational castes as socially backward and classified them as "other backward castes" (OBCs).

To measure the economic status, we created a "household wealth index" using principal component analysis of different household assets and dwelling characteristics (type of floor, roof, etc) based on methods previously described. ${ }^{16}$ The household wealth index was then used to divide the population into five quintiles.

STATA 7.0 was used to carry out statistical analyses. ${ }^{17}$ Univariate analysis was done to assess the distribution of the sample and to compute overall prevalence of chewing of tobacco/pan masala and smoking of tobacco. Both point estimates and robust 95\% confidence intervals (based on robust standard errors after adjusting for strata and clustering at primary sampling unit (PSU) level are presented. The sample based prevalence estimates were converted into population based estimates taking into account the population of India as per the Census 2001. Bivariate and multivariate logistic regression models were estimated to assess the unadjusted and adjusted association, respectively, of different socioeconomic (household wealth, years of schooling, religion, and caste) and demographic characteristics (urban/rural residence, sex and age) with tobacco consumption. Both bivariate and multivariate regression models were estimated after applying for sampling weights and adjusting for multi-stage clustered sampling designs using "svy" command in STATA 7.0. Collinearity between explanatory variables was tested using variance inflation factor (VIF) command in STATA, which was found to be insignificant. MAPINFO software was used to produce thematic maps of male tobacco smoking and chewing prevalence.

\section{RESULTS}

\section{Overall prevalence}

Sixteen per cent of the study population $(29.3 \%$ men and $2.3 \%$ women) smoked tobacco; $20 \%$ of the study population (28.1\% men and $12.0 \%$ women) chewed tobacco/pan masala; and $30 \%$ of the study population $(46.5 \%$ men and $13.8 \%$ women) either smoked or chewed tobacco. Table 2 shows the percentage and approximate number of people who consumed some form of tobacco. Approximately, 194 million people aged 15 years and older (150 million men and 44 million women) consumed some form of tobacco. Almost $79 \%$ of tobacco consumers lived in rural areas, slightly more than the share of rural population in the total population $(73 \%)$.

\section{State level variation}

The prevalence of both smoking and chewing tobacco/pan masala varied significantly among different states in India (table 3, fig 1). Some regional patterns were observed for chewing tobacco/pan masala. Chewing of tobacco was relatively more common in the Central, Eastern, Western (except Goa) and Northeastern states (except Meghalaya) compared to in the Northern and Southern states. However, in the Northern states, where chewing is relatively less common, smoking of tobacco is relatively higher (except in Punjab where tobacco prevalence is one of the lowest as majority of its population (58\%) practice Sikh religion, which prohibits tobacco consumption).

\section{Demographic and socioeconomic predictors Unadjusted relationships}

Columns $2-4$ and columns 6-8 of tables 4 and 5, respectively, summarise the prevalence and unadjusted odds of smoking and chewing in different socioeconomic and demographic groups by sex. The change in prevalence of tobacco consumption with age is also shown in fig 2 . The prevalence of both smoking and chewing tobacco increased prominently with age until 50 years and then remains constant or declined. Compared to chewing, the smoking prevalence declined more steeply after 50 years of age among men.

The prevalence of both chewing tobacco/pan masala and smoking tobacco was significantly higher in rural, poorer, and uneducated populations compared to urban, wealthier, and more educated populations, respectively, both in men and women, though the differentials for chewing tobacco were smaller. The socioeconomic gradients (by household wealth as well as by education) were steeper for women than for men for both chewing tobacco/pan masala and smoking tobacco. Men in the poorest quintile have 3.5 times higher

Table 2 Prevalence of smoking and chewing tobacco/pan masala in India, 1998-99

\begin{tabular}{|c|c|c|c|c|c|}
\hline & & \multicolumn{2}{|l|}{ Men } & \multicolumn{2}{|c|}{ Women } \\
\hline & & $\%$ use & Millions & $\%$ use & Millions \\
\hline \multicolumn{6}{|l|}{ Smoking } \\
\hline & Urban & 21.4 & 19.7 & 0.8 & 0.7 \\
\hline & Rural & 32.5 & 74.6 & 3.0 & 6.9 \\
\hline & Total & 29.3 & 94.3 & 2.4 & 7.6 \\
\hline \multicolumn{6}{|l|}{ Chewing } \\
\hline & Urban & 20.7 & 19.1 & 8.6 & 7.6 \\
\hline & Rural & 31.1 & 71.4 & 13.3 & 30.4 \\
\hline & Total & 28.1 & 90.4 & 12.0 & 38.0 \\
\hline \multicolumn{6}{|l|}{ Smoking or chewing } \\
\hline & Urban & 35.6 & 32.8 & 9.2 & 8.1 \\
\hline & Rural & 50.9 & 116.9 & 15.5 & 35.5 \\
\hline & Total & 46.5 & 149.6 & 13.8 & 43.6 \\
\hline
\end{tabular}


Table 3 State level prevalence of tobacco consumption in India by sex

\begin{tabular}{|c|c|c|c|c|c|c|c|c|}
\hline \multirow[b]{3}{*}{ Region/state } & \multicolumn{4}{|c|}{ Smoking } & \multicolumn{4}{|c|}{ Chewing } \\
\hline & \multicolumn{2}{|l|}{ Men } & \multicolumn{2}{|c|}{ Women } & \multicolumn{2}{|l|}{ Men } & \multicolumn{2}{|c|}{ Women } \\
\hline & $\%$ & $95 \% \mathrm{Cl}$ & $\%$ & $95 \% \mathrm{Cl}$ & $\%$ & $95 \% \mathrm{Cl}$ & $\%$ & $95 \% \mathrm{Cl}$ \\
\hline \multicolumn{9}{|l|}{ North } \\
\hline New Delhi & 23.9 & 22.0 to 25.9 & 1.8 & 1.4 to 2.2 & 13.1 & 11.5 to 14.9 & 2.5 & 1.9 to 3.2 \\
\hline Haryana & 40.4 & 37.7 to 43.1 & 3.5 & 2.8 to 4.3 & 8.1 & 6.7 to 9.8 & 0.9 & 0.6 to 1.3 \\
\hline Himachal Pradesh & 38.6 & 36.6 to 40.6 & 2.4 & 1.8 to 3.1 & 7.8 & 6.7 to 9.1 & 0.5 & 0.3 to 0.8 \\
\hline Jammu \& Kashmir & 44.3 & 42.0 to 46.6 & 8.3 & 7.1 to 9.7 & 7.3 & 5.8 to 9.1 & 0.9 & 0.6 to 1.3 \\
\hline Punjab & 13.9 & 12.2 to 15.8 & 0.3 & 0.2 to 0.5 & 9.3 & 8.0 to 10.8 & 0.2 & 0.1 to 0.4 \\
\hline Rajasthan & 37.8 & 35.7 to 39.9 & 4.1 & 3.2 to 5.2 & 19.0 & 17.7 to 20.4 & 3.8 & 2.9 to 4.9 \\
\hline \multicolumn{9}{|l|}{ Central } \\
\hline Madhya Pradesh & 29.4 & 27.6 to 31.1 & 0.9 & 0.6 to 1.2 & 40.3 & 38.7 to 42.0 & 14.4 & 12.7 to 16.2 \\
\hline Uttar Pradesh & 33.8 & 32.5 to 35.2 & 3.0 & 2.6 to 3.5 & 36.3 & 34.6 to 38.0 & 10.9 & 10.1 to 11.8 \\
\hline \multicolumn{9}{|l|}{ East } \\
\hline Bihar & 26.3 & 24.8 to 27.9 & 6.2 & 5.5 to 7.0 & 51.8 & 50.1 to 53.5 & 6.7 & 6.0 to 7.6 \\
\hline Orissa & 25.2 & 23.2 to 27.2 & 0.9 & 0.7 to 1.2 & 49.0 & 46.7 to 51.4 & 34.3 & 31.9 to 36.9 \\
\hline $\begin{array}{l}\text { West Bengal } \\
\text { North-East }\end{array}$ & 39.4 & 37.4 to 41.5 & 2.5 & 2.0 to 3.2 & 23.2 & 20.9 to 25.6 & 15.1 & 13.5 to 17.0 \\
\hline Assam & 31.5 & 28.4 to 34.9 & 2.6 & 2.0 to 3.4 & 47.8 & 44.7 to 51.0 & 24.3 & 22.1 to 26.6 \\
\hline Arunachal Pradesh & 25.6 & 23.1 to 28.2 & 5.6 & 4.2 to 7.3 & 51.6 & 47.9 to 55.3 & 33.1 & 29.6 to 36.7 \\
\hline Manipur & 35.0 & 32.0 to 38.1 & 12.0 & 10.0 to 14.2 & 34.1 & 31.1 to 37.3 & 19.2 & 15.5 to 23.5 \\
\hline Meghalay & 55.2 & 50.6 to 59.7 & 6.7 & 4.2 to 10.6 & 16.9 & 13.8 to 20.5 & 27.6 & 23.8 to 31.7 \\
\hline Mizoram & 59.4 & 57.0 to 61.8 & 22.0 & 19.6 to 24.6 & 60.2 & 56.5 to 63.8 & 60.7 & 57.2 to 64.0 \\
\hline Nagaland & 38.0 & 34.3 to 41.8 & 2.4 & 1.3 to 4.5 & 45.0 & 41.3 to 48.8 & 16.5 & 13.7 to 19.7 \\
\hline Sikkim & 19.4 & 17.1 to 22.0 & 8.2 & 6.9 to 9.7 & 39.5 & 36.5 to 42.7 & 18.6 & 16.2 to 21.2 \\
\hline Tripura & 48.5 & 44.9 to 52.2 & 9.7 & 6.7 to 13.9 & 10.8 & 8.9 to 13.1 & 5.2 & 3.3 to 8.1 \\
\hline \multicolumn{9}{|l|}{ West } \\
\hline Goa & 17.8 & 16.1 to 19.6 & 2.0 & 1.2 to 3.2 & 7.7 & 6.0 to 9.9 & 8.0 & 6.3 to 10.2 \\
\hline Gujarat & 25.3 & 23.5 to 27.2 & 1.4 & 1.0 to 1.8 & 24.6 & 22.8 to 26.4 & 8.0 & 7.0 to 9.2 \\
\hline Maharashtra & 13.3 & 12.1 to 14.6 & 0.2 & 0.1 to 0.4 & 34.1 & 32.3 to 36.0 & 18.0 & 16.1 to 20.0 \\
\hline \multicolumn{9}{|l|}{ South } \\
\hline Andhra Pradesh & 35.4 & 33.4 to 37.5 & 4.2 & 3.5 to 4.9 & 10.7 & 9.4 to 12.0 & 9.9 & 8.4 to 11.7 \\
\hline Karnataka & 25.7 & 24.1 to 27.4 & 0.3 & 0.2 to 0.4 & 13.8 & 12.1 to 15.6 & 14.1 & 12.7 to 15.7 \\
\hline Kerala & 28.2 & 26.5 to 30.0 & 0.4 & 0.3 to 0.7 & 9.4 & 8.3 to 10.7 & 10.1 & 9.1 to 11.2 \\
\hline Tamil Nadu & 27.0 & 25.4 to 28.8 & 0.3 & 0.2 to 0.6 & 12.9 & 11.5 to 14.5 & 10.7 & 9.3 to 12.2 \\
\hline
\end{tabular}

A Male tobacco smoking

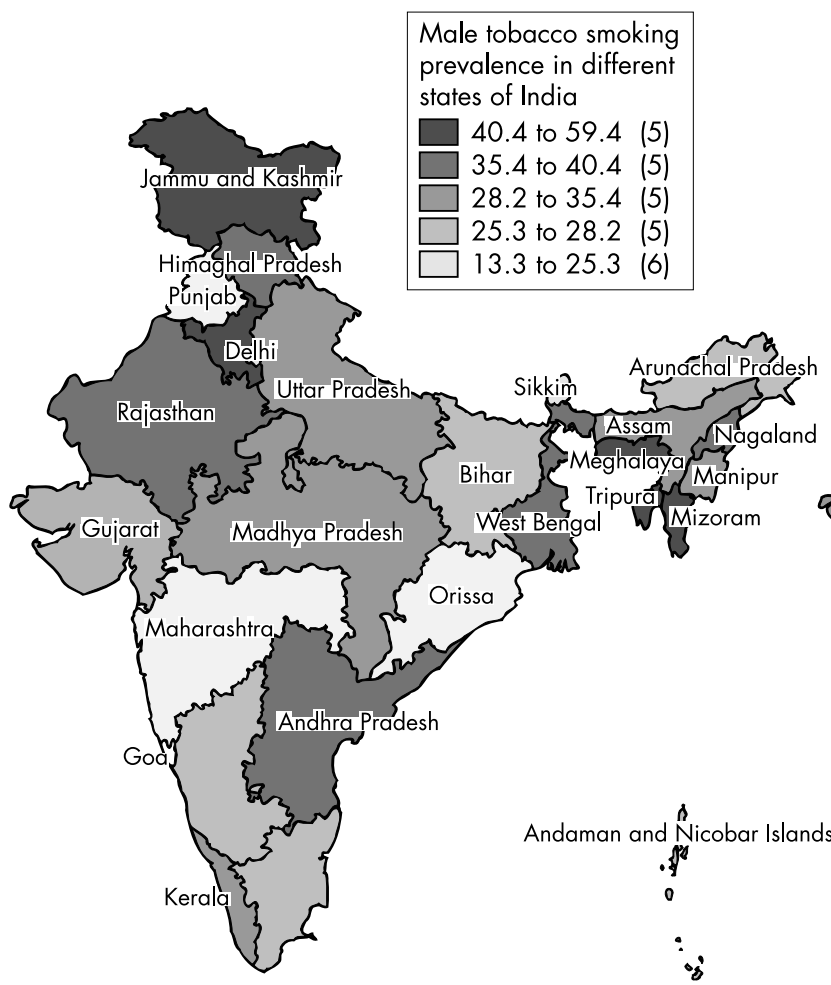

B Male tobacco chewing

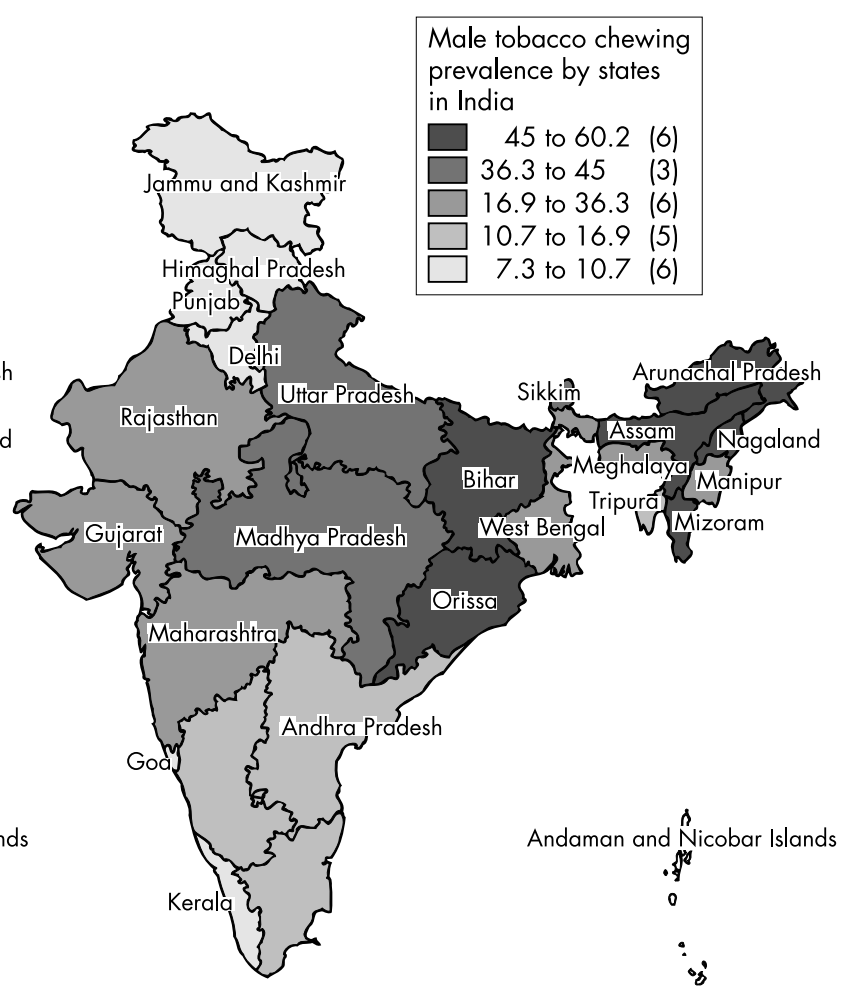

Figure 1 Prevalence of male tobacco smoking and tobacco chewing in different states of India. 
Table 4 Unadjusted prevalence rates and odds ratios derived from bivariate (unadjusted) and multivariate logistic regression (adjusted) for tobacco smoking

\begin{tabular}{|c|c|c|c|c|c|c|c|c|}
\hline \multirow{3}{*}{$\begin{array}{l}\text { Variable } \\
\text { (reference group) }\end{array}$} & \multicolumn{4}{|l|}{ Men } & \multicolumn{4}{|c|}{ Women } \\
\hline & \multicolumn{2}{|c|}{ Prevalence (\%) } & \multicolumn{2}{|l|}{ Odds ratio } & \multicolumn{2}{|c|}{ Prevalence (\%) } & \multicolumn{2}{|l|}{ Odds ratio } \\
\hline & $\%$ & $95 \% \mathrm{Cl}$ & Unadjusted & Adjusted $\dagger$ & $\%$ & $95 \% \mathrm{Cl}$ & Unadjusted & Adjusted $†$ \\
\hline \multicolumn{9}{|l|}{ Age $(R C=15-24$} \\
\hline years) & 8.6 & 8.2 to 9.0 & 1.00 & 1.00 & 0.4 & 0.3 to 0.5 & 1.00 & 1.00 \\
\hline $25-39$ & 32.8 & 32.2 to 33.6 & $5.19^{* *}$ & $5.51^{* *}$ & 1.7 & 1.6 to 1.9 & $4.73^{* *}$ & $4.08^{* *}$ \\
\hline $40-59$ & 45.1 & 44.2 to 46.0 & $8.72^{\star *}$ & $9.23^{* *}$ & 4.7 & 4.4 to 5.1 & $13.2^{* *}$ & $11.76^{* *}$ \\
\hline $\begin{array}{l}\text { 60+ } \\
\text { Residence }\end{array}$ & 38.1 & 37.1 to 39.1 & $6.53^{* *}$ & $5.54^{\star *}$ & 5.2 & 4.8 to 5.7 & $14.7^{* *}$ & $12.95^{\star *}$ \\
\hline (RC= urban) & 21.4 & 20.6 to 22.2 & 1.00 & 1.00 & 0.8 & 0.7 to 1.0 & 1.00 & 1.00 \\
\hline Rural & 32.5 & 31.9 to 33.0 & $1.77^{* *}$ & 0.98 & 3.0 & 2.8 to 3.2 & $3.63^{* *}$ & 1.22 \\
\hline \multicolumn{5}{|l|}{ Household wealth } & 0.5 & 0.4 to 0.6 & 1.00 & 1.00 \\
\hline 2nd richest & 25.7 & 25.0 to 26.4 & $1.82^{\star *}$ & $1.53^{\star \star}$ & 1.3 & 1.2 to 1.4 & $2.51^{* *}$ & $1.57^{\star *}$ \\
\hline Middle & 31.6 & 30.8 to 32.4 & $2.42^{* *}$ & $1.94^{* *}$ & 2.4 & 2.1 to 2.6 & $4.61^{* *}$ & $2.68^{* *}$ \\
\hline 2nd poorest & 36.4 & 35.5 to 37.3 & $3.00^{* *}$ & $2.11^{* *}$ & 3.3 & 3.0 to 3.7 & $6.57^{* *}$ & $3.26^{* *}$ \\
\hline \multicolumn{8}{|c|}{ Years of schooling } & $4.32^{* *}$ \\
\hline$(R C=11+$ years $)$ & 12.8 & 12.3 to 13.4 & 1.00 & 1.00 & 0.1 & 0.1 to 0.2 & 1.00 & 1.00 \\
\hline $6-10$ years & 22.3 & 21.8 to 22.8 & $1.95^{\star *}$ & $1.84^{\star *}$ & 0.3 & 0.2 to 0.3 & $2.71^{*}$ & 1.73 \\
\hline $1-5$ years & 36.9 & 36.1 to 37.7 & $3.97^{* *}$ & $2.72^{* *}$ & 0.9 & 0.8 to 1.1 & $8.83^{* *}$ & $2.82^{*}$ \\
\hline No education & 45.3 & 44.5 to 46.1 & $5.62^{* *}$ & $3.17^{\star \star}$ & 4.1 & 3.9 to 4.4 & $40.6^{* *}$ & $6.25^{\star *}$ \\
\hline $\begin{array}{l}\text { Caste ( } R=\text { forward } \\
\text { caste) }\end{array}$ & \multicolumn{8}{|c|}{ Caste $(R=$ forward } \\
\hline Scheduled caste & 35.2 & 34.3 to 36.1 & $1.58^{* *}$ & $1.20^{* *}$ & 3.4 & 3.0 to 3.8 & $2.05^{* *}$ & $1.34^{* *}$ \\
\hline Scheduled tribe & 34.4 & 32.4 to 36.5 & $1.53^{* *}$ & 1.05 & 3.9 & 3.3 to 4.5 & $2.37^{* *}$ & $1.49^{*}$ \\
\hline $\begin{array}{l}\text { Other b } \\
\text { castes }\end{array}$ & 28.1 & 27.3 to 28.8 & $1.14^{* *}$ & 1.01 & 2.3 & 2.1 to 2.6 & $1.4^{* *}$ & 1.09 \\
\hline Religion $(R C=$ Hindu $)$ & 29.5 & 29.0 to 30.1 & 1.00 & 1.00 & 2.4 & 2.2 to 2.6 & 1.00 & 1.00 \\
\hline Muslim & 32.0 & 30.5 to 33.5 & $1.12^{*}$ & $1.10^{*}$ & 2.7 & 2.3 to 3.1 & 1.1 & 1.14 \\
\hline Christian & 31.3 & 5.2 to 7.6 & 1.09 & 1.02 & 0.1 & .01 to 0.2 & 1.3 & 1.10 \\
\hline Sikh & 6.3 & 29.3 to 33.4 & $0.16^{* *}$ & $0.15^{\text {** }}$ & 3.1 & 2.5 to 3.9 & $0.02^{* *}$ & $0.05^{* *}$ \\
\hline Other & 19.4 & 16.7 to 22.5 & $0.57^{* *}$ & 0.89 & 1.7 & 1.1 to 2.6 & 0.71 & 0.79 \\
\hline
\end{tabular}

${ }^{*} \mathrm{p}<0.05 ;{ }^{* *} \mathrm{p}<0.001$.

$\mathrm{Cl}$, confidence intervals; OR, odds ratios; RC, reference category.

†25 dummy variables representing state of residence were also included in the multivariate regression model to adjust for the state of residence (results not shown in the table).

unadjusted odds for smoking and 3.7 times higher unadjusted odds for chewing tobacco than among men from the richest quintile, while the similar figures among women were 9.9 times for smoking and 4.8 times for chewing tobacco. Men with no schooling had 5.6 times higher unadjusted odds of smoking and 3.1 times higher unadjusted odds of chewing tobacco than men with more than 11 years of schooling, while in women the unadjusted odds were 41 times higher for smoking and 13 times higher for chewing tobacco.

Prevalence of chewing tobacco/pan masala was the highest among the scheduled tribe (ST) population and lowest among forward castes and other backward castes (OBC). The forward castes were also least likely to smoke tobacco. While no significant differences were seen in the prevalence of smoking and chewing tobacco/pan masala among Hindu, Muslim, and Christian populations, the Sikh population had a significantly lower prevalence of tobacco consumption.

\section{Multivariate analysis: adjusted relationships}

Column 5 and column 9 in table 4 (for smoking) and table 5 (for chewing tobacco/pan masala) present the adjusted odds ratios from multivariate logistic regression models to tease out the adjusted association between different socioeconomic and demographic characteristics and adjusted odds of chewing and smoking tobacco. Though the relations observed in bivariate analysis persisted in multivariate analysis, the effect of certain sociodemographic variables got diluted after controlling for other confounding socioeconomic characteristics.

Compared to the younger population (15-24 years), the older population (25+ years) had a greater likelihood of both chewing and smoking tobacco. In the multivariate analysis, the number of school years emerged as one of the strongest predictors-in terms of odds ratio-for both smoking and chewing among both men and women followed by household wealth. Scheduled castes and scheduled tribes were more likely to smoke and chew tobacco compared to the forward castes (except for smoking among men where no significant differentials were observed among ST, OBC, and forward castes), even after controlling for household wealth and education. Compared to Hindus, Muslim men were more likely to smoke, though no differentials were observed among women. However, Muslim women were more likely to chew tobacco than Hindu women. Sikh religion emerged as one of the strongest predictord among both men and women for not chewing or smoking tobacco. The differentials by state of residence also persisted in the multivariate analysis (not shown in tables 4 and 5).

No significant association was observed between urban/ rural residence and smoking or chewing of tobacco/pan masala among men after controlling for other characteristics. However, rural women were less likely to chew tobacco than urban women (odds ratio 0.87, $\mathrm{p}<0.05$ ).

\section{DISCUSSION}

\section{Prevalence}

This is the first study to provide nationally representative aggregate prevalence estimates of tobacco consumption by different socioeconomic and demographic characteristics. Though superior to the existing studies in terms of study design and representativeness, this study also suffers from several data limitations, which may potentially affect the 
Table 5 Unadjusted prevalence rates and odds ratios derived from bivariate (unadjusted) and multivariate logistic regression (adjusted) for chewing of tobacco

\begin{tabular}{|c|c|c|c|c|c|c|c|c|}
\hline \multirow{3}{*}{$\begin{array}{l}\text { Variable } \\
\text { (reference group) }\end{array}$} & \multicolumn{4}{|l|}{ Men } & \multicolumn{4}{|c|}{ Women } \\
\hline & \multicolumn{2}{|c|}{ Prevalence } & \multicolumn{2}{|l|}{ Odds ratio } & \multicolumn{2}{|c|}{ Prevalence } & \multicolumn{2}{|l|}{ Odds ratio } \\
\hline & $\%$ & $95 \% \mathrm{Cl}$ & Unadjusted & Adjusted $t$ & $\%$ & $95 \% \mathrm{Cl}$ & Unadjusted & Adjusted $\dagger$ \\
\hline Age $(R C=15-24$ years $)$ & 4.4 & 4.2 to 4.6 & 1.00 & 1.00 & 14.3 & 13.8 to 14.9 & 1.00 & 1.00 \\
\hline $25-39$ & 17.2 & 16.8 to 17.6 & $2.77^{* *}$ & $3.10^{* *}$ & 31.6 & 30.9 to 32.3 & $3.65^{\star *}$ & $3.26^{\text {** }}$ \\
\hline $40-59$ & 25.7 & 25.2 to 26.2 & $3.27^{* *}$ & $3.72^{\star *}$ & 35.3 & 34.5 to 36.1 & $8.03^{* *}$ & $7.17^{* *}$ \\
\hline $60+$ & 22.4 & 21.7 to 23.0 & $3.58^{* *}$ & $3.71^{\text {** }}$ & 37.4 & 36.3 to 38.5 & $10.40^{\star *}$ & $8.47^{* *}$ \\
\hline Residence $(R C=$ urban $)$ & 20.7 & 19.7 to 21.7 & 1.00 & 1.00 & 8.6 & 7.9 to 9.3 & 1.00 & 1.00 \\
\hline $\begin{array}{l}\text { Rural } \\
\text { Household wealth }\end{array}$ & 31.1 & 30.4 to 31.8 & $1.73^{* *}$ & 0.97 & 13.3 & 12.8 to 13.8 & $1.63^{* *}$ & $0.87^{*}$ \\
\hline ( $R C=$ richest $20 \%$ ) & 16.4 & 15.6 to 17.2 & 1.00 & 1.00 & 4.8 & 4.5 to 5.2 & 1.00 & 1.00 \\
\hline 2nd richest & 22.8 & 22.0 to 23.7 & $1.51^{* *}$ & $1.40^{* *}$ & 9.3 & 8.7 to 9.8 & $2.02^{* *}$ & $1.52^{* *}$ \\
\hline Middle & 28.1 & 27.3 to 28.9 & 1.99 ** & $1.55^{* *}$ & 12.6 & 12.0 to 13.2 & $2.85^{\star *}$ & $1.92^{\text {** }}$ \\
\hline 2 nd poorest & 34.4 & 33.4 to 35.4 & $2.68^{* *}$ & $1.69^{* *}$ & 15.6 & 14.4 to 15.9 & $3.53^{\star *}$ & $2.15^{\star *}$ \\
\hline Poorest $20 \%$ & 41.9 & 40.7 to 43.2 & $3.69^{* *}$ & $1.93^{* *}$ & 19.6 & 18.7 to 20.6 & $4.84^{* *}$ & $2.58^{* *}$ \\
\hline $\begin{array}{l}\text { Years of schooling } \\
(R C=1]+\text { years) }\end{array}$ & 169 & 162 to 177 & 100 & 100 & 16 & & & \\
\hline 6-10 years & $\begin{array}{l}10.7 \\
23.7\end{array}$ & 23.1 to 24.3 & $1.52^{\text {** }}$ & $1.48^{\text {** }}$ & $\begin{array}{l}1.6 \\
4.3\end{array}$ & 4.0 to 4.6 & $\begin{array}{l}1.00 \\
2.82^{* *}\end{array}$ & $\begin{array}{l}1.00 \\
2.05^{\star *}\end{array}$ \\
\hline $1-5$ years & 33.0 & 32.1 to 33.9 & $2.42^{* *}$ & $1.86^{* *}$ & 11.5 & 10.8 to 12.1 & $8.16^{* *}$ & $3.81^{* *}$ \\
\hline No education & 38.6 & 37.6 to 39.6 & $3.08^{* *}$ & $1.92^{\text {** }}$ & 17.2 & 16.6 to 17.8 & $13.10^{* *}$ & $4.97^{* *}$ \\
\hline Caste $(R C=$ forward & & & & & & & & \\
\hline caste) & 24.2 & 23.4 to 25.1 & 1.00 & 1.00 & 9.5 & 8.9 to 10.1 & 1.00 & 1.00 \\
\hline Scheduled caste & 30.4 & 29.1 to 31.8 & $1.37^{* *}$ & $1.12^{*}$ & 14.6 & 13.7 to 15.5 & $1.62^{\star *}$ & $1.34^{\star *}$ \\
\hline Scheduled tribe & 41.1 & 39.1 to 43.1 & $2.18^{* *}$ & $1.23^{* *}$ & 20.8 & 19.2 to 22.4 & $2.49^{* *}$ & $1.43^{* *}$ \\
\hline Other backward castes & 28.3 & 27.2 to 29.4 & $1.24^{\star *}$ & $1.07^{*}$ & 10.8 & 10.1 to 11.4 & $1.14^{*}$ & 1.01 \\
\hline Religion ( $R C=$ Hindu) & 29.1 & 28.6 to 29.7 & 1.00 & 1.00 & 12.0 & 11.5 to 12.5 & 1.00 & 1.00 \\
\hline Muslim & 25.5 & 24.0 to 27.1 & $0.83^{* *}$ & $0.90^{*}$ & 13.0 & 12.1 to 14.0 & $1.10^{*}$ & $1.52^{\star *}$ \\
\hline Christian & 9.3 & 8.0 to 10.8 & $0.57^{* *}$ & $0.85^{*}$ & 0.1 & 0.04 to 0.3 & 0.96 & $0.76^{*}$ \\
\hline Sikh & 19.1 & 17.0 to 21.4 & $0.25^{\text {** }}$ & $0.70^{*}$ & 11.5 & 10.1 to 13.2 & $0.01^{\text {** }}$ & $0.08^{\text {** }}$ \\
\hline Other & 31.5 & 27.6 to 35.7 & 1.12 & 0.98 & 18.4 & 15.3 to 21.9 & $1.66^{* *}$ & 1.22 \\
\hline
\end{tabular}

${ }^{*} \mathrm{p}<0.05 ;{ }^{* *} \mathrm{p}<0.001$.

$\mathrm{Cl}, 95 \%$ confidence intervals; $\mathrm{OR}$, odds ratios; $\mathrm{RC}$, reference category.

†25 dummy variables representing state of residence were also included in the multivariate regression model to adjust for the state of residence (results not shown in the table).

prevalence estimates. The first step in validating the estimates from the NFHS-2 survey may be to compare the estimates from earlier studies while noting the methodological differences that may be responsible for the observed differences. Table l summarises prevalence estimates of tobacco consumption arrived in previous studies, and comparable estimates from the NFHS-2 survey. The prevalence rates estimated from NFHS-2 are slightly lower for smoking, but higher for chewing than the estimates arrived in the 52nd NSS, which used the same sampling methodology and household informants (table 1). However, the questions were phrased differently in the two surveys that may partly account for the differences. For example, while

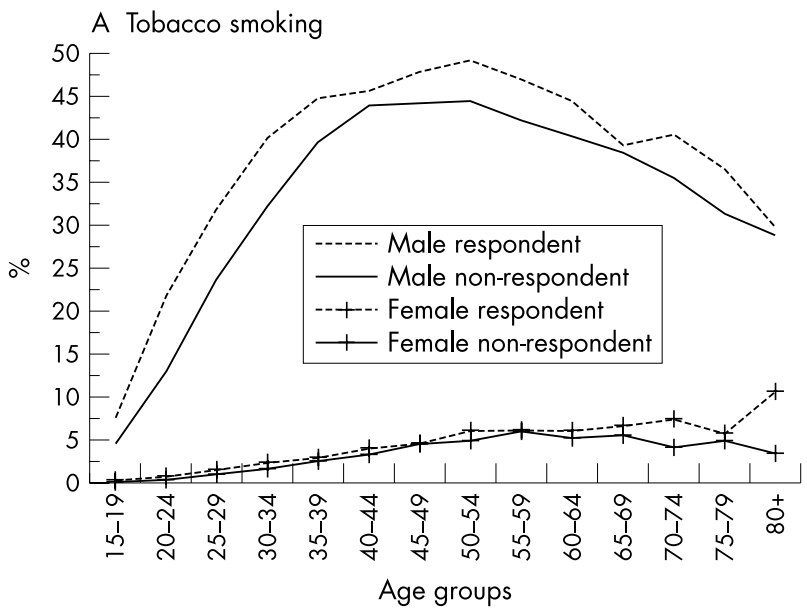

the question on chewing tobacco was very ambiguous in the 52nd NSS as discussed earlier in the first section, NFHS-2 explicitly asked about chewing tobacco as well as about chewing paan masala. Similarly, while the 52nd NSS explicitly probed for all forms of smoking tobacco (biri/cigar/cigarette/ hukka), NFHS-2 simply asked whether any household member "smokes tobacco", leaving the interpretation of "tobacco" to the respondents themselves, which may explain the lower estimates of smoking prevalence in NFHS-2.

However, the estimates from both the NFHS-2 and the 52nd NSS using proxy household informants are lower than the prevalence rates of tobacco consumption estimated by $\mathrm{WHO},{ }^{1}$ based on small studies conducted in India in different

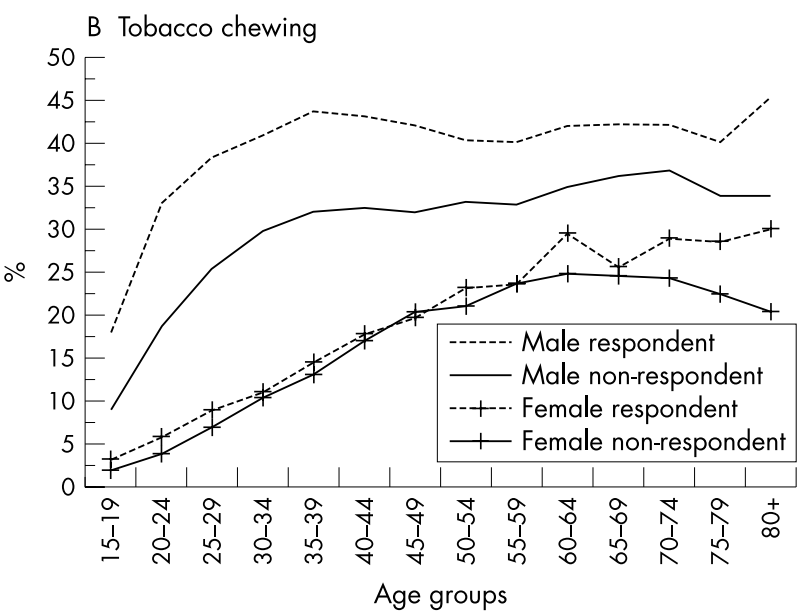

Figure 2 Prevalence of tobacco consumption by age categories in women and men. 
time periods, and also from those of other small studies based on special population groups in small geographical areas (table 1). Use of household informants in NFHS-2 who may not be aware of the use of tobacco by other household members rather than the individual self reports used in most of the earlier small scale studies (table 1) may be partly responsible for the differences observed, besides the differences in the reference population groups in these studies. To estimate the potential degree of under-reporting in NFHS-2 due to use of household informants, the prevalence of tobacco consumption was estimated separately among household respondents themselves and among other household members (table 6). The age adjusted prevalence rates in the household respondents' population were higher among men and women, respectively, by almost $10.6 \%$ and $1.5 \%$ for chewing tobacco and by $5.4 \%$ and $0.5 \%$ for smoking tobacco. When examined by age group (table 6, fig 2), the underreporting is consistently higher in the younger age groups among both men and women. Though a recent study conducted in Delhi ${ }^{18}$ found a high degree of agreement between individual self reports and household informant reports for tobacco use, results from this study show that prevalence may be underestimated when it is elicited through a household informant. Taking into account all the limitations of the study and the previous literature on prevalence of tobacco consumption in India, it is safe to conclude that the study provides robust lower bound estimates for the prevalence of tobacco consumption in India. The real estimates may be almost $11 \%$ and $1.5 \%$ higher for chewing among men and women, respectively. Similarly the prevalence of smoking may be underestimated by almost $5 \%$ in men and $0.5 \%$ in women.

\section{State level variation}

The odds of tobacco consumption varied significantly across different Indian states even after controlling for individuallevel socio-economic and demographic characteristics. For example, the chewing prevalence was distinctly higher in Central and Eastern India, and in the Northeastern states. The state level variation may reflect distinct regional sociocultural patterns or effect of different public policies on tobacco in different states. Future studies should explore the reasons for inter-state differentials as this can provide important insights into effect of different public policies and their interaction with local socio-cultural patterns on use of tobacco.

\section{Poverty and illiteracy}

Tobacco consumption was the highest in the least educated, poorest, and scheduled castes and scheduled tribes. Though systematic under-reporting of tobacco use in some social groups due to differentials in social stigma attached with tobacco use in different sociodemographic groups may have contributed to this apparent trend, it is unlikely to account completely for the trends observed, considering the very wide differentials. The socioeconomic differentials in tobacco consumption from this study also compare well with the findings from previous studies in India ${ }^{10}{ }^{11}{ }^{19}$ and elsewhere. ${ }^{20}$

Why poor or less educated people consume more tobacco remains an open empirical question for further investigation. Education emerged as a relatively stronger predictor than household wealth, both among men and women. It is likely that poor and less educated people are: less aware of the health hazards of tobacco consumption; more likely to find themselves in conditions predisposing them to initiation of smoking and chewing of tobacco; and more likely to have higher degree of fatalism or higher overall risk taking behaviour. ${ }^{20}$ The findings of the study highlight that an agenda to improve health outcomes for the poor and other disadvantaged groups in India must also include effective interventions to control tobacco, as these groups may suffer from disproportionate burden of tobacco induced morbidity and mortality. In addition, each intervention should be evaluated for its effectiveness separately in different socioeconomic and cultural groups, since access and effectiveness of different programmatic strategies may vary across these groups.

\section{Demographics of tobacco consumption}

The cross sectional nature of the data did not allow us to assess the trends in tobacco consumption over time or with age. The observed increase in prevalence of tobacco consumption with age can be due to a cohort effect (declining prevalence over time with younger cohorts having lower prevalence) or an age effect (younger people having lower prevalence, with more people initiated into tobacco consumption as they get older) or simply due to under reporting of tobacco use among young people. Previous literature suggests no declining trends in tobacco consumption over time in India. As indicated earlier, the differences in the prevalence of tobacco use between respondent and nonrespondent population is much higher in the 15-24 year age group (fig 2, table 6). However, as is very clear in fig 2, trends in prevalence rates with age are very similar in both

\begin{tabular}{|c|c|c|c|c|c|c|}
\hline \multirow[b]{2}{*}{ Sex and age } & \multicolumn{3}{|c|}{ Chewing tobacco/pan masala } & \multicolumn{3}{|c|}{ Smoking tobacco } \\
\hline & Respondent & Non-respondent & Difference & Respondent & Non-respondent & Difference \\
\hline \multicolumn{7}{|l|}{ Men } \\
\hline Total $^{*}$ & 36.4 & 25.8 & 10.6 & 33.7 & 28.3 & 5.4 \\
\hline $15-24$ & 27.8 & 13.0 & 14.8 & 16.8 & 7.8 & 9.0 \\
\hline $25-39$ & 41.1 & 28.6 & 12.5 & 39.0 & 30.9 & 8.1 \\
\hline $40-59$ & 41.6 & 32.4 & 9.2 & 47.4 & 44.0 & 3.4 \\
\hline $\begin{array}{l}60+ \\
\text { Women }\end{array}$ & 42.0 & 35.4 & 6.6 & 40.7 & 37.0 & 3.7 \\
\hline Total $^{*}$ & 13.3 & 11.7 & 1.5 & 2.8 & 2.3 & 0.5 \\
\hline $15-24$ & 4.9 & 2.7 & 2.2 & 0.6 & 0.3 & 0.3 \\
\hline $25-39$ & 11.3 & 9.5 & 1.8 & 2.1 & 1.5 & 0.6 \\
\hline $40-59$ & 20.1 & 20.3 & -0.2 & 4.6 & 4.8 & -0.2 \\
\hline $60+$ & 28.2 & 23.7 & -4.5 & 6.7 & 4.8 & 1.9 \\
\hline
\end{tabular}

Respondents ( $n=92012)$ and non-respondents $(n=242548)$.

*The totals are adjusted for age (as the age structure of respondent and non-respondent population differed significantly) by using the national population as the standard population to account for the age differences in the respondent and non-respondent population. 
What this paper adds

The findings of the study will help in designing tobacco control strategies and understanding the epidemiology of tobacco related health burden in India.

respondent and non-respondent sub-samples (table 6, fig 2). Hence the observed increase in tobacco prevalence is the partly the result of under-reporting in the younger age groups and party due to an actual increase in prevalence of tobacco consumption with age up to mid 50s (fig 2). This has important policy and programme implications-the initiation into tobacco use may occur at any age and not just among young people. This implies that programmes to control tobacco have to focus on almost all age groups up to the age of 50 .

\section{Conclusion}

In India, as in most low income countries, death in middle age is increasing in relative importance due to an increase in smoking related deaths. ${ }^{21}$ The disease burden, health care costs as well as other fiscal losses resulting from premature deaths attributable to tobacco consumption will rapidly increase. ${ }^{82-24}$ Earlier WHO estimates suggest that deaths and disability adjusted life years (DALYs) attributable to tobacco use in India will increase from 129000 deaths and 1719 DALYs in 1990 to over 1.5 million deaths and 24024 DALYs by $2002 .{ }^{8}$ The high levels of tobacco consumption among disadvantaged population groups may lead to a doubling of the disease burden in these social groups from chronic illnesses related to tobacco consumption as well as from communicable and nutrition related diseases, which still account for a large share of total disease burden in the disadvantaged social groups in India. In addition to the differences in prevalence of tobacco consumption between disadvantaged and better off groups, the type and amount of tobacco consumption, which are shown to be directly associated with incidence of tobacco related diseases and mortality, may also vary between the two, further aggravating the differences in disease burden attributable to tobacco between the two groups. ${ }^{19}$ Though no data were collected in the NFHS- 2 on the type and amount of tobacco consumed, which remains one of the weaknesses of survey, other studies suggest that the poor are $8-10$ times more likely to smoke bidis $^{22}{ }^{25}$ that may lead to greater risk of oropharyngeal and lung cancer in this group than among the better off. ${ }^{725}$

The public policy implications of our study are twofold. Research on tobacco use needs to be considerably systematised with use of more consistent definitions of tobacco consumption and study methodologies. More rigorous comparable prevalence studies over time are needed to establish the trends in prevalence and evaluate the effect of different public policies pursued to control tobacco use. Though studies involving use of household informants are much more economical and easier to administer than those based on individual self reports, the prevalence may be underestimated and need to be adjusted upwards to provide real estimates. In addition, future studies should investigate the prevalence rates of different tobacco products (both smoking and chewing tobacco) separately, as the economic and health effects of different products may vary considerably, and because of the potential differences in prevalence of use of different tobacco products across different sociodemographic groups.

\section{ACKNOWLEDGEMENTS}

The authors acknowledge the contribution of three anonymous referees for their valuable revisions, especially for the analysis relating to underestimation of tobacco use prevalence due to use of surrogate household respondents.

\section{Authors' affiliations}

*M Rani, *S Bonu, Indian Administrative Services, Jaipur, India P Jha, L Jamjoum, Centre for Global Health, St Michael's Hospital, and International Tobacco Evidence Network, University of Toronto, Toronto, Ontario, Canada

S N Nguyen, Word Bank, Washington DC, USA

*Study was conducted while on study leave at Johns Hopkins Bloomberg School of Public Health

\section{REFERENCES}

1 WHO. Tobacco or health: a global status report. Geneva: World Health Organization, 1997.

2 Gupta R, Prakash H, Gupta VP, et al. Prevalence and determinants of coronary health disease in a rural population in India. J Clinl Epidemiol 1997:50:203-9.

3 Padmavati S. Prevention of heart disease in India in the $21^{\text {st }}$ century. Need for a concerted effort. Indian Heart J 2002;54:99-102.

4 Vora AR, Yeoman CM, Hayter JP. Alcohol, tobacco and paan use and understanding of oral cancer risk among Asian men in Leicester. Br Dental J 1997; 188:441-51.

5 Franceschi S, Bidoli E, Herrero R, et al. Comparison of cancers of the oral cavity and pharynx worldwide: etiological clues. Oral Oncology 2000;36:106-15

6 Moore SR, Johnson NW, Pierce AM, et al. The epidemiology of tongue cancer: a review of global incidence. Oral Diseases 2000;6:75-84.

7 Dikshit R, Kanhere S. Tobacco habits and risk of lung, oropharyngeal and oral cavity cancer: a population-based case-control study in Bhopal, India. Int J Epidemiol 2000;29:609-14.

8 Murray CJ, Lopez AD, eds. The global burden of disease: a comprehensive assessment of mortality and disability from diseases, injuries and risk factors in 1990 and projected to 2020. Cambridge, Massachussets: Harvard School of Public Health, 1996.

9 Kutty RV, Balakrishnan KG, Jayashree AK, et al. Prevalence of coronary heart disease in the rural population of Thiruvanatnthapuram district, Kerala, India. Int J Cardiol 1993;39:59-70.

10 Venkat Narayan KM, Chadha SL, Hanson RL, et al. Prevalence and patterns of smoking in Delhi: cross sectional study. BMJ 1996;312:1576-9.

11 Gupta PC. Survey of socio-demographic characteristics of tobacco use among 99,598 individuals in Bombay, India using handheld computers. Tobacco Control 1996;5: 1 14-20.

12 Gupta R, Prakash H, Gupta VP, et al. Prevalence and determinants of coronary health disease in a rural population in India. J Clin Epidemiol 1997;50:203-9.

13 Shah S, Vaite S. Choosing tobacco over food: daily struggles for existence among the street children of Mumbai, India. In: Efroymson D, ed. Tobaco and poverty: observation from India and Bangladesh 2002. PATH, Canada. http://wbb.globalink.org/public/tobacco_poverty.PDF (Internet communication, 30 January 2003).

14 Shah S, Vaite S. Pavement dwellers in Mumbai, India: priortizing tobacco over basic needs. In: Efroymson D, ed. Tobacco and poverty: observation from India and Bangladesh 2002. PATH, Canada. http://wbb.globalink.org/ public/tobacco_poverty.PDF (Internet communication, 30 January 2003).

15 IIPS. National family health survey-II (1998-1999). Bombay: International Institute of Population Studies, 2000.

16 Filmer D, Pritchett L. Estimating wealth effects without wealth or expenditure data: Educational enrollment in India. Memo, DECRG, The World Bank, Washington, DC, 1998. http://www.worldbank.org/html/dec/Publications/ Workpapers/WPS1900series/wps 1994/wps 1994.pdf (Internet communication 30 January 2003).

17 StataCorp. Stata statistical software: Release 7.0. College Station, Texas: Stata Corporation, 2001.

18 Mohan D, Neufeld K, Chopra A, et al. Agreement between head of household informant and self-report in a community survey of substance use in India. Drug and Alcohol Dependence 2003;69:87-94.

19 Peters DH, Yazbeck AS, Sharma RR, et al. Better health systems for India's poor: findings, analysis, and options. Washington DC: World Bank, 2002.

20 Bobak M, Jha P, Nguyen S, et al. Poverty and smoking. In: Jha P, Chaloupka FJ, eds. Tobacco control in developing countries. Oxford: Oxford University Press, 2000.

21 Jha P, Ranson MK, Nguyen SN, et al. Estimates of global and regional smoking prevalence in 1995, by age and sex. Am J Public Health 2002;92:1002-6.

22 Gajalakshmi CK, Jha P, Ranson K, et al. Global patterns of smoking and smoking attributable mortality. In: Jha P, Chaloupka FJ, eds. Tobacco control in developing countries. Oxford: Oxford University Press, 2000.

23 Jha P, Chaloupka FJ. Curbing the epidemic: governments and the economics of tobacco control. Washington DC: World Bank, 1999.

24 Jha P, Chaloupka FJ. Tobacco control in developing countries. New York: Oxford University Press, 2000.

25 Malson JL, Sims K, Murty R, et al. Comparison of the nicotine content of tobacco used in bidis and conventional cigarettes. Tobacco Control 2001;10:181-3. 